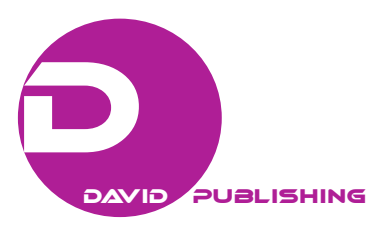

\title{
Islamic Banks Impaired Financing: Relationship Between Shariah Committee Meetings Frequency and Shariah Risks Compliance on Assets Quality
}

\author{
Mohd Yaziz Bin Mohd Isa \\ Universiti Tun Abdul Razak Kuala Lumpur, Malaysia
}

\begin{abstract}
This study made a pioneering attempt to econometrically examine what factors determining impaired financing using shariah committee meetings frequency from data on Islamic banks in Malaysia and how does it affects on the quality of assets. The objective of the study is to improve assessment of their assets quality so as to increase the reliability of the financial statements. The European Central Bank may find the findings from this study useful in their exercise to assess risks and assets quality of their commercial banks, a move to tackle the ailing banks in centralizing oversight supervision in late 2014. The major components of the Islamic banks' assets quality are impaired financing and provisions for financing impairment. In the Islamic banks, shariah committee principally manages the shariah risks non-compliance with other risks; however because their management is not straightforward, the study uses the shariah committee meetings frequency as an indicator of the assets quality. The study found the less-than-full frequency of shariah committee meetings resulted in less guidance and conformation of shariah principles, and consequentially the quality of the assets.
\end{abstract}

Keywords: Islamic banks, impaired financing, shariah meetings frequency, shariah risks compliance.

\section{Introduction}

Islamic banks perform a role to provide capital from depositors with surplus funds to skilled entrepreneurs to undertake productive contract activities. The deposits from the depositors constitute the bank's liabilities and the contracts to the entrepreneurs represent the bank's assets. The difference between returns or yields from investments of the entrepreneurs, and the returns to the depositors comprises the bank's "spread" which is an element of profitability. The bank's margin is a "spread" between interest revenue on bank assets and interest expense on bank liabilities. Hutapea \& Kasri (2010) analyze between Islamic banks and conventional banks in Indonesia, revealed whilst the conventional banks responded positively to interest rate movements by adjusting their loans and deposit interest rates to the movements, the Islamic banks responded negatively to the profit rate movements.

On the one hand the ability of the banks to provide capital is dependent on the deposits the quality of the contacts of the entrepreneurs has effect on the banks' solvency. As such, all Islamic banks have formed shariah committee whose duties and responsibilities are to ensure the contracts are in compliance and conformation to

Corresponding author: Mohd Yaziz Bin Mohd Isa, Universiti Tun Abdul Razak Kuala Lumpur, Malaysia. 
shariah principles. The principles are the Islamic divine guidance derived from main three sources: the Quran and the Hadith - sayings of the Prophet Mohammed, peace be upon him (the two non-arguable sources); and the Sunnah - the practice and traditions of the Prophet Mohammed, peace be upon him. However, some of the Islamic banks report increasing trends in their impaired financing as a percentage of total assets during the last three years as tabulated in Table 1.1:

Table 1.1

Percentage of impaired financing over total assets

\begin{tabular}{llll}
\hline Islamic bank: & FYE 2010 & FYE 2011 & FYE 2012 \\
\hline Affin Islamic & 1.1 & 1.6 & 2.0 \\
AmIslamic & 0.2 & 0.99 & 1.6 \\
Bank Islam & 0.8 & 1.17 & 1.81 \\
Bank Muamalat & 1.77 & 2.06 & 1.27 \\
CIMB Islamic & 0.73 & 0.99 & 0.88 \\
Maybank Islamic & 0.56 & 1.07 & 2.1 \\
RHB Islamic & 1.59 & 2.47 & 4.79 \\
AlRajhi Bank & 1.5 & 2.3 & 3.3 \\
HSBC Amanah & 1.0 & 1.2 & 1.0 \\
OCBC AlAmin & 0.7 & 0.8 & 1.0 \\
Bank Rakyat & 0.8 & 0.9 & 2.5 \\
\hline
\end{tabular}

Source: Banks annual report

Among the contracts in the Islamic banks, the two main contracts are mudarabah and musharaka, and between these two, the "credit risk (the risk that the entrepreneur would fail in its contractual obligations in accordance to agreed terms) is higher for musharaka than mudarabah" (Khan \& Porzio, 2010, p. 103). The paper proceeds as follows: chapter 2 is a literature review and chapter 3 is discussions on research framework and data. Chapter 4 is a discussion of empirical results, and chapter 5 concludes.

\section{Literature Review}

The literature on efficiency and productivity of commercial banks is enormous. Delis \& Papanikolaou (2009) discover private owners of the commercial banks do not always aim at achieving efficiency. Earlier, Grigorian \& Manole (2006) discover that ownership with controlling power enhanced efficiency of the commercial banks. However, studies on Islamic banks assets quality are very scarce. The scarcity in the studies is despite the growing popularity of Islamic finance as an alternative to conventional finance. This paper makes pioneering attempts to examine the effect of shariah risks compliance for all 24 Islamic banks of the Association of Islamic Banks in Malaysia (AIBM). The purpose is to analyze the impact of the shariah risks compliance on the assets quality as measured by a major indicator, the impaired financing (IF). Other indicators of assets quality are provisions or allowances for financing impairment (also referred to as "loan loss provisions (LLP)" in the conventional finance), loss reserves, and maturity match, according to Beck, Demigruc-Kunt \& Merrouche (2013). The impaired financing (IF) is used in this study although according to Shan \& Xu (2011) from their studies on dilemma of bad debt provisions of conventional commercial banks in China, the loan loss provisions (LLP) is a better proxy of bad debts than the reported NPL because it may subsequently be reclassified to performing status.

In the Islamic banks, it is well acknowledged that a shariah committee principally manages the shariah 
non-compliance risks i.e. the risks arising from the failure to comply with shariah rules and principles. Apart from shariah non-compliance risks, the banks also deal with other risks such as rate of return risk, displaced commercial risk and equity investment risk; however as their management in the context of Islamic finance is not straightforward according to Ahmad Tajudin, 2010; this study uses as the basis, the shariah committee meetings frequency as an indicator of the Islamic banks' assets quality. Cholopichien (2008) in her dissertation on the relationship on quality of directors to the level of voluntary disclosure among listed companies in Thailand uses attendance of the directors at their meetings as a variable to measure the influences in form and strength of the relationship. In the dissertation, she also refers to earlier study by Vafeas, 1999 who used board meetings frequency as a variable to examine the qualities of directors. In a later study, Yunos, 2011 refers to Raghunandan \& Rama (2007) who documented that frequent meetings are reflective of active committee members. In a more recent study, Tong et al. 2013 in the analysis on Chinese state-owned enterprise firm's boards conclude that meetings frequency is positively related to performance.

\section{Research Framework and Data}

\section{Research Framework}

The study applies the Generalized Method of Moments (GMM) developed for dynamic model by Arellano \& Bond (1991). The model is more appropriate according to Fonseca \& Gonzalez (2008) who use it on a sample of 1213 banks in 40 countries, in order to control for:

unobservable individual banks' specific effects (arising from different guidance, conformations and interpretations from the shariah committee members. It is measured by their average meetings frequency during the time they held office, and that their assets quality will regress to reflect on the shariah committee meetings frequency).

(1) likely endogeneity of the explanatory variables; and

(2) the auto regressive process in the data regarding the behavior of Impaired Financing (IF), and its uses as a lagged variable in period $\mathrm{t}-1$ in order to capture its dynamic nature.

(3) The relationship between variables thus is expressed as follows:

(4) $\mathrm{IF} / \mathrm{TA}=\mathrm{a}+\mathrm{b} \mathrm{SH}+\mathrm{c}(\mathrm{IF} / \mathrm{TA})_{i t-1}+\mathrm{e}$

In the above expression, the dependent variable is IF ("Impaired Financing") which is the impaired financing of the Islamic banks reflecting their assets quality. The independent variables are Shariah (SH) and the lagged Impaired Financing (IF).

The independent variable is dependent firstly on SH ("Shariah"), average percentage of meetings frequency of the shariah committee the time they held office "divides by or over" shariah committee meetings held. The shariah committee members comprises of shariah scholars therefore the higher the frequency of the meetings provides suggestive evidence the better is the guidance and conformation of shariah principles from the scholars in effecting on the quality of assets.

However, where the information on the frequency of the shariah risks committee is not available the board risks management meetings frequency during the time they held office can be used as a proxy. The board risks management committee governs banks' key risks areas, policy and appetite.

Secondly, the Impaired Financing (IF) is dependent also on its lagged (IF/TA) t-1 to capture adjustments that constrain complete adjustment to an equilibrium level that is, change in the speed of adjustment in the 
impaired financing beyond the first year. The reason to capture the adjustment beyond the first year is the appointment of the Shariah committee is for a two-year term. Also, in order to normalize to mitigate the estimation problems with heterogeneity effects, which are common due to their differences in total assets among the banks, the total assets (TA) is used as denominator as proposed by Fonseca \& Gonzalez, 2008 in their estimation model.

The variable SH ("Shariah") apart as an independent variable may be also a moderating variable in order to measure the moderating effect on the Impaired Financing to show the effect is stronger or change in form for banks with full-frequency; and less strong or non-existent, or change in form for banks with less-than-full-frequency of the meetings. This is as documented by Sharma et al. (1981) the moderating variable moderates either the form and/or strength of the relationship among independent variables, and the "pure" moderating variable "enter(s) into interaction with predictor variables, while having a negligible correlation with the criterion itself" Sharma et al. refers to Cohen \& Cohen (1975), (p. 314). In order to test the moderating effect, the interaction term is entered into the regression equation, and the model fit is (re)calculated to determine for any significant change, in the way that is tested by Al-Shammari, O'Brien \& AlBusaidi (2013) in testing the moderating effects of "ownership structure" on firm performance.

Also, in this instance "shariah knowledge" can be a mediator variable as it accounts and explains why there is a relation between the meetings frequency and Impaired Financing. Such that when the mediator ("shariah knowledge") is removed, the effect of the moderating variable ("meetings frequency") on the independent variable ("Impaired Financing”) disappears (Baron \& Kenny, 1986).

Where the variable SH ("Shariah") is a moderating variable, the equation is re-written as:

$\mathrm{IF} / \mathrm{TA}=\mathrm{a}+\mathrm{b} \mathrm{SH}+\mathrm{c}(\mathrm{IF} / \mathrm{TA})_{\mathrm{it}-1}+\mathrm{d} \mathrm{SH}\left((\mathrm{IF} / \mathrm{TA})_{\mathrm{it}-1}\right)+\mathrm{e}$, where $\mathrm{d}$ is a parameter estimate of the interaction term.

\section{Data}

The observation periods cover the last three years up to 2013, and the analysis comprises 24 member banks of the Association of Islamic Banks In Malaysia (AIBIM). The association's members consisting 10 domestic Islamic banks, 2 development financial institutions and 9 locally-incorporated foreign banks operating in Malaysia and 3 International Financial Institutions. The association members are as tabulated below, and their shariah meeting frequency are also tabulated below:-

Table 3.2.1

Domestic Islamic banks (10) - full-fledged Islamic banking operations

\begin{tabular}{|l|l|}
\hline No. & Name \\
\hline 1. & Affin Islamic Bank Berhad \\
\hline 2. & Alliance Islamic Bank Berhad \\
\hline 3. & AmIslamic Bank Berhad \\
\hline 4. & Bank Islam (Malaysia) Berhad \\
\hline 5. & Bank Muamalat (Malaysia) Berhad \\
\hline 6. & CIMB Islamic Bank Berhad \\
\hline 7. & Hong Leong Islamic Bank Bhd \\
\hline $8 .$. & Maybank Islamic Berhad \\
\hline 9. & Public Islamic Bank Berhad \\
\hline 10. & RHB Islamic Bank Berhad \\
\hline
\end{tabular}


Table 3.2.2

Development Financial Institutions (2)

\begin{tabular}{|c|c|}
\hline No. & Name \\
\hline 1. & Bank Kerjasama Rakyat Malaysia Berhad- a full-fledged Islamic cooperative bank \\
\hline 2. & $\begin{array}{l}\text { Bank Simpanan Nasional (BSN) } \\
\cdot \quad \text { analysis of Islamic banking operations three years up to } 2011\end{array}$ \\
\hline
\end{tabular}

Table 3.2.3

Locally Incorporated Foreign Banks (9) - Observations covered Islamic banking operations

\begin{tabular}{|c|c|}
\hline No. & Name \\
\hline 1. & Al Rajhi Banking \& Investment Corporation Berhad \\
\hline 2. & Asian Finance Bank Berhad \\
\hline 3. & $\begin{array}{l}\text { BNP Paribas Malaysia Berhad } \\
\text { - excluded in the analysis as the bank only started its operation of Islamic banking window since } 2012 \text {. }\end{array}$ \\
\hline 4. & $\begin{array}{l}\text { Bank Of Tokyo-Mitsubishi UFJ (M) Berhad } \\
\text { • only } 1 \text { year figures are included }\end{array}$ \\
\hline 5. & Citibank Berhad \\
\hline 6. & HSBC Amanah Malaysia Berhad \\
\hline 7. & $\begin{array}{l}\text { Kuwait Finance House (Malaysia) Berhad } \\
\text { - excluded in the analysis because lack of information on meetings frequency }\end{array}$ \\
\hline 8. & OCBC Al-Amin bank Berhad \\
\hline 9. & $\begin{array}{l}\text { Standard Chartered Saadiq Berhad } \\
\text { - whilst meetings frequency is that of Shariah committee; figures analyzed are conventional banking operations as lack } \\
\text { of information on figures from Islamic banking operations }\end{array}$ \\
\hline
\end{tabular}

Table 3.2.4

International Financial Institutions (3)

\begin{tabular}{|l|l|}
\hline No. & Name \\
\hline 1. & AlKHAIR International Islamic Bank Berhad- lack of information on figures \\
\hline 2. & $\begin{array}{l}\text { Elaf Bank B.S.C } \\
\bullet \quad \text { lack of information on figures }\end{array}$ \\
\hline 3. & $\begin{array}{l}\text { P.T. Bank Muamalat Indonesia Tbk } \\
\bullet \quad \text { lack of information on figures }\end{array}$ \\
\hline
\end{tabular}

Table 3.2.5

Shariah meetings frequency

\begin{tabular}{llll}
\hline Islamic banks & FYE 2010 & FYE 2011 & FYE 2012 \\
\hline Affin Islamic Bank Berhad & 1.00 & 1.00 & 0.97 \\
AmIslamic Bank & 0.95 & 1.00 & 0.96 \\
Bank Muamalat & 0.943 & 0.866 & 0.946 \\
CIMB Islamic & 0.85 & 0.833 & 0.93 \\
Hong Leong Islamic & $\mathrm{N} / \mathrm{a}$ & $\mathrm{N} / \mathrm{a}$ & 0.96 \\
Maybank Islamic & $\mathrm{N} / \mathrm{a}$ & $\mathrm{N} / \mathrm{a}$ & 0.972 \\
RHB Islamic & 0.916 & 0.942 & 0.885 \\
Al Radji & 0.83 & 0.722 & 0.89 \\
Asian Finance & 1.00 & 0.95 & 0.917 \\
Bank Of Tokyo-Mitsubishi UFJ & $\mathrm{N} / \mathrm{a}$ & $\mathrm{N} / \mathrm{a}$ & 0.92 \\
\hline
\end{tabular}


Table 3.2 .5 continued

\begin{tabular}{llll}
\hline Islamic banks & FYE 2010 & FYE 2011 & FYE 2012 \\
Citibank Malaysia & 0.893 & 0.9 & 0.938 \\
HSBC Amanah & 0.86 & 0.812 & 0.97 \\
OCBC AlAmin & 0.979 & 0.98 & 0.925 \\
Standard Chartered Saadiq & 0.895 & 0.78 & 0.949 \\
Bank Rakyat & 0.782 & 0.86 & 0.91 \\
Bank Simpanan Nasional & 1.0 & 1.0 & 0.893 \\
\hline
\end{tabular}

Source: Banks annual report

\section{Discussions of Empirical Results}

The tables 4.1 and 4.1 (i) show regression results obtained using the Generalized Method of Moments (GMM) analysis.

Table 4.1

Regression results using E Views version 8

\begin{tabular}{|c|c|c|c|c|}
\hline \multicolumn{5}{|c|}{ Dependent Variable: Impaired Financing (IF) } \\
\hline \multicolumn{5}{|c|}{ Method: Generalized Method of Moments } \\
\hline \multicolumn{5}{|c|}{ Cross-sections included: 24} \\
\hline Variable & Coefficient & Std. Error & t-statistics & Prob. \\
\hline Constant (C) & 0.002145 & 0.010434 & 0.205550 & 0.8390 \\
\hline Shariah $(\mathrm{SH})$ & 0.000275 & 0.010959 & 0.025091 & 0.9802 \\
\hline $\begin{array}{l}\text { Impaired Financing (IF)/ } \\
\text { Total Assets }{ }_{\mathrm{t}-1}\end{array}$ & 0.985284 & 0.277188 & 3.554598 & 0.0017 \\
\hline \multicolumn{5}{|l|}{ Effects specification } \\
\hline R-squared & 0.586176 & \multicolumn{2}{|c|}{ Mean dependent var } & 0.017108 \\
\hline Adjusted R-squared & 0.550191 & \multicolumn{2}{|c|}{ S.D. dependent var } & 0.009289 \\
\hline S.E. of regression & 0.006230 & \multicolumn{2}{|l|}{ J-statistic } & 4.351290 \\
\hline Sum squared resid & 0.000893 & \multicolumn{2}{|c|}{ Instrument rank } & 4 \\
\hline
\end{tabular}

The regression coefficient $\mathrm{R}^{2}$ of 0.586176 shows fit of the regression model to the data indicating $58.6176 \%$ of the variance of impaired financing is explained by the shariah risks committee meetings frequency during the time they held office, and by the lagged impaired financing beyond the first year. The positive sign of Impaired Financing in year t-1 indicates guidance and conformations from the shariah risks committee during the time they held office has contained any further deterioration in the assets quality in subsequent years.

When the interaction term between the shariah and the independent variables is entered into the regression equation, the results indicate a significant increase in the model fit to $\mathrm{R}^{2}$ to 0.639079 The full results are as tabulated in table 4.1 (i) below:

With the increase in the model fit after the interaction term is entered into the regression equation provides evidence that the moderating variable SH ("Shariah") strengthens the relationship between the independent and dependent variables. In other words, the relationship being stronger in the (Islamic) banks with higher frequency of the ("shariah committee") meetings; and the negative coefficient of the moderating variable of -5.224108 shows the moderating variable negatively moderates the relationship in that the more frequent is the ("shariah committee") meetings, the lower is the impaired assets ("Impaired Financing"). 
Table 4.1 (i)

Regression results using $E$ Views version 8 (interaction term is entered in the regression equation).

\begin{tabular}{|c|c|c|c|c|}
\hline \multicolumn{5}{|c|}{ Dependent Variable: Impaired Financing (IF) } \\
\hline \multicolumn{5}{|c|}{ Method: Generalized Method of Moments } \\
\hline \multicolumn{5}{|c|}{ Cross-sections included: 24} \\
\hline Variable & Coefficient & Std. Error & t-statistics & Prob. \\
\hline Constant (C) & -0.062535 & 0.018402 & -3.398246 & 0.0027 \\
\hline Shariah $(\mathrm{SH})$ & 0.071215 & 0.020314 & 3.505754 & 0.0021 \\
\hline $\begin{array}{l}\text { Impaired Financing (IF)/ } \\
\text { Total Assets } \\
\mathrm{t}-1\end{array}$ & 5.743519 & 1.289465 & 4.454186 & 0.0002 \\
\hline Moderating & -5.224108 & 1.449427 & -3.604256 & 0.0017 \\
\hline \multicolumn{5}{|l|}{ Effects specification } \\
\hline R-squared & 0.639079 & \multicolumn{2}{|c|}{ Mean dependent var } & 0.017311 \\
\hline Adjusted R-squared & 0.587519 & \multicolumn{2}{|c|}{ S.D. dependent var } & 0.009422 \\
\hline S.E. of regression & 0.006051 & \multicolumn{2}{|l|}{ J-statistic } & 3.398266 \\
\hline Sum squared resid & 0.000769 & \multicolumn{2}{|c|}{ Instrument rank } & 5 \\
\hline
\end{tabular}

\section{Concluding Remarks}

The regression coefficient $\mathrm{R}^{2}$ is at the calculated level may be explained by the less-than-full frequency at shariah risks committee. This translates to lesser guidance and conformation of shariah risks principles from members, and consequentially on the assets quality of the banks. The differing opinions in assessment of impaired financing among Islamic scholars due to lacking of synchronization in the interpretations of Islamic laws on transactions as discovered by Ghannadian \& Goswami (2004), may be an additional explanatory contributing factor that the regression coefficient $\mathrm{R}^{2}$ is at the calculated level. Future researches can explore to dissect in determining impaired financing and assets quality employing similar methodology i.e. the shariah committee meetings frequency, but for nonprofit-loss-sharing activities which are also permitted by shariah in order to discern from the profit-loss-sharing activities. Grassa, Rihab (2012) observes that Islamic banks in recent years have diversified into other nonprofit-loss-sharing activities modes of financing because the profit-loss-sharing products are more risky, require more costly monitoring; and because they encounter several inconveniences to manage and control them.

\section{References}

Ahmad Tajudin, Azrul, Azwar (2010), "Islamic Finance course and instruments", Bank Negara Malaysia, The Islamic Development Bank, 13 December p. 1-18

Al-Shammari, Hussam, O’Brien, W. Ross \& AlBusaidi, Yousuf (2013), "Firm internationalization and IPO firm performance: The moderating effects of firm ownership structure", International Journal of Commerce and Management, vol., 23, no. 3, p. $242-261$

Arellano, Manuel \& Bond, Stephen (1991), "Some Tests Specifications for Panel Data: Monte Carlo Evidence and An Application to Employment Equations”, Review of Economic Studies, volume 58, no. 2 April, 1991, p. 277-297

Baron, R. M., \& Kenny, D. A. (1986), “The moderator-mediator variable distinction in social psychological research: Conceptual, strategic, and statistical considerations", Journal of Personality and Social Psychology, 51, 1173-1182.

Beck, Thorsten, Demigruc-Kunt, Asli \& Merrouche, Ouarda (2013), "Islamic vs. conventional banking: Business model, efficiency and stability”, Journal of Banking \& Finance Issue 37, vol. 2, February, 2013 p. 422-447

Cohen, Jacob \& Patricia, Cohen (1975), “Applied Multiple Regression/Correlation Analysis for the Behavioral Science”, Hillsdale, New Jersey, Lawrence Erlbaum Associates 
Cholopichien, Jakkravudhi (2008), "The quality of board of directors, ownership structure and level of voluntary disclosure of listed companies in Thailand", University of Science Malaysia, June, p. 1-287

Delis, Manthos D. \& Papanikolaou, Nikolas I. (2009), "Determinants of bank efficiency evidence from a semi-parametric methodology", Managerial Finance, volume 35, no. 3, 2009, p. 260-275

Fonseca, Ana Rosa \& Gonzalez, Francisco, (2008), "Cross-country determinants of bank income smoothing by managing loan loss provisions", Journal of Banking and Finance, Vol., 32, No.2, p. 217-228

Grassa, Rihab (2012), “Islamic banks' income structure and risk: evidence from GCC countries”, Journal of Accounting Research, vol., 25, no. 3, p. 227-241.

Hutapea, Erwin G. \& Kasri, Rahmatina A. (2010), "Bank margin determination: a comparison between Islamic and conventional banks in Indonesia", International Journal of Islamic and Middle Eastern Finance and Management, vol., 3, Issue 1, p. 65-82

Ghannadian, Farhad F., \& Goswami, Gautam, (2004), "Developing Economy Banking: the case of Islamic banks", International Journal of Social Economics, vol., 31, no. 8, p. 740-752

Grigorian, D.A. \& Manole, V. (2006), "Determinants of commercial bank performance in transition: an application of data envelopment analysis", Comparative Economic Studies, vol. 48, no. 3, p. 497-522

Khan, M. Fahim \& Porzio, Mario, (2010), "Islamic Banking and Finance in the European Union. A Challenge" Edward Elgar Publishing Ltd.

Raghunandan, K., \& Rama, D. V. (2007), “Determinants of Audit Committee Diligence”, Accounting Horizons, vol. 21(3), p. 265-279.

Sharma, Subhash, Durand, Ricahrd M., \& Gur-Arie, Oded (1981), "Identification and Analysis of Moderator Variables", Journal of Marketing Research, vol. XVII August, 1981, p. 291-300

Tong, Shenghui, Junarsin, Eddy \& Davidson III, Wallace N., “A Comparison of Chinese State-Owned enterprise Firms' Boards and Private Firm's Boards", Proceedings of 23rd International Business Research Conference, 18 - 20 November, 2013, Melbourne, Australia

Vafeas, N., (1999), "Board meeting frequency and firm performance” Journal of Financial Economics vol. 53, p. 113-142

Yunos, Rahimah, (2011), "The Effect of Ownership Concentration, Board of Directors, Audit Committee and Ethnicity on Conservative Accounting: Malaysian Evidence” Edith Cowan University, Perth, Australia p.1-232 